\title{
Center and Periphery in the Late Antiquity (on the Example of Bosporus)
}

\author{
A. L. Yermolin \\ The Zinman Institute of Archaeology, University of Haifa \\ 199 Aba-Hushi Avenue, Haifa, 3498838, Israel \\ E-mail: doryerm@yandex.ru
}

Copyright: (C) 2020 Yermolin, A. L. This is an open-access publication distributed under the terms of the Creative Commons Attribution License, which permits unrestricted use, distribution, and reproduction in any medium, provided the original authors and source, the Tractus Aevorum journal, are credited.

Continuing the theme of the center and periphery of the late antique world, one should pay attention to the unique phenomenon of its cultural mosaic, the extreme northeast, the Cimmerian Bosporus, located in eastern Crimea and on the Taman Peninsula.

In late antiquity, the Bosporus was the only independent state of ancient origin, which was not included in the empire. Thus, it represents the only version of a statehood alternative to imperial. It can be called peripheral late antique. It was the northern outpost of the ecumenical community against the barbarians and, at the same time, a transit point that developed an independent model of the coexistence of the Greek and barbarian worlds.

In late antiquity, which in relation to the Bosporus covers the chronological framework from the middle of the $3^{\text {rd }}$ to the end of the $6^{\text {th }}$ century, the Bosporus experienced difficult times. The crisis of the empire in the $3^{\text {rd }}$ century influenced the Bosporus. Crimea and the Bosporus lay on the path of the Great Migration, but continued to maintain diverse ties with the empire. This determined the specifics and unique path of the Bosporus as a northern and semi-barbaric periphery, but still part of the late antique world.

The turning point in the history of the Bosporus was the middle of the $3^{\text {rd }}$ century. At that time, tribes of Goths, Gerul and Boran appeared in the Northern Black Sea region, and from the east Sarmatian-Alan tribes were moving, which the Bosporus kingdom could not resist. Many cities and settlements were destroyed. The dynasty of the last Bosporan kings Rescuporis' preferred political submission and loyalty to the barbarians in order to maintain the integrity of the region. In particular, in the middle of

ISSN 2312-3044 | http://belsu-tractus-aevorum.ru 
the $3^{\text {rd }}$ century, the Goths and Borans were provided with ships on which they attacked Greece and the Pontic coast of Asia Minor: Cappadocia, Bithynia.

The Bosporus state decreased during these events. A new western border passed along the Cimmerian wall, to the west of which the settlements disappeared. In the former half of the $4^{\text {th }}$ century, a significant event took place in the cultural life of the Bosporus, a diocese was formed. Bishop Cadmus went to the Ecumenical Council in Nicaea in 325. Nevertheless, the diocese was small and insignificant, taking the last position in the lists of acts of the Council of Cadmus.

In the first third of the $4^{\text {th }}$ century, the Bosporus was firmly in the sphere of influence of the Romans, having established cultural and economic ties with the empire, as evidenced by the silver vessels from Kerch with the image of Constantius II.

However, by the middle of the century, there was a decline in political power in the Bosporan state, as indicated by the cessation of coinage. In 362, the Bosporians sent an embassy to Emperor Julian ofering tribute in exchange for protection. The decline is associated with the Gothic threat, for it was then that the Gothic power of Germanaric was formed in the Crimea.

In the late $4^{\text {th }}$ century the Hun invasion, apparently, passed the main centers of the Bosporus and did not bring catastrophic destruction.

By the early 5th century, the Goths fleeing the Huns settled in the southeast of Crimea, on the Kerch Peninsula, replenishing the composition of the Bosporus population and nobility. By the first half of the $5^{\text {th }}$ century there were a large number of rich Gothic burials in the necropolises of Panticapaeum-Bosporus. It is believed that the Goths established their protectorate over the Bosporus. The Bosporus at that time was in economic decline and saw naturalization and rustification of the economy from the latter half of the $4^{\text {th }}$ century.

Nevertheless, trade relations continued. Themisty reports about the grain trade between the empire and the Bosporus in the 380s. Also, many Christian burial inscriptions appeared during the $5^{\text {th }}$ century.

In the 430s, Bosporus fell under control of Hun tribes, which reached Panticapaeum and later became an integral part of Attila's state. However, the Huns were nomads and could not live in cities. Thus, most likely, the Bosporyans remained semi-independent and paid tribute. The power of the Huns on the Bosporus intensified after the collapse of the Hunish state of Attila, when they settled near the Bosporus (the tribe of Utigurs).

In the latter half of the $5^{\text {th }}$ century the Utigur Huns became allies of the empire. In a building inscription of the early $6^{\text {th }}$ century, Bosporan king Duptun is referred to as the "friend of Caesars" and the "pious" king, who built the defensive tower, probably at the expense of and on the orders of the imperial authorities. The administrative structure of the Bosporus of that time also reproduced the imperial structure (comites, protocomites, eparchs, masters, secretaries, etc.). At that time, the Christianization and 
cultural influence of Byzantium intensified. Thus, a number of Christian inscriptions were found with the words of prayers and psalms in the Kerch catacombs, one of the most famous in the collection of the noble Bosporan Christian, Savag, dated 491.

In the first third of the $6^{\text {th }}$ century, under Emperor Justin I, according to Procopius of Caesarea, "the Bosporians gave themselves under the authority of the emperor". The emperor sent a force there (an arithmos of Spanish stratiotai led by Apoipath John), which in the early 520s placed Bosporus under the control of the empire to the desire of the inhabitants. In addition to the Greek Bosporus itself, Byzantium spread its influence to the surrounding tribes, actively subjected to Christianization. The Hun leader of the Utigurs, Grod, received baptism from the hands of the emperor. After his murder by fellow tribesmen, Justinian sent an army by sea and land and finally annexed the Bosporus to the empire. An inscription mentioning Justinian was found dated 533. As a result, Byzantine possessions in Crimea spread from Bosporus to Kherson. Justinian pursued an active construction policy, fortifying the destroyed walls of Bosporus, Kherson and other cities in the 530-540s. Fanagoria and Kepy had been plundered by Utigurs, but by the middle of the $6^{\text {th }}$ century they already looked like Byzantine provincial cities. He also introduced a new bishop to the Tetraxite Goths. They became federates of the empire and sent their troops against the hostile Kutrigur Huns.

Byzantine-Bosporus trade was developing. The Bosporus was a significant trading center on the border of the Byzantine and barbarian worlds. In Panticapaeum-Bospor, in the layers of the $6^{\text {th }}$ century, there are a lot of Greek ceramics and coins: amphorae, red-varnished ceramics, glass vessels were imported. It is believed that along with shipbuilding and trade, salting of fish on an industrial scale continued to be carried out in the Bosporus. Byzantine traces are also observed in other cities, in particular, in the port city of Citea, which existed in the $6^{\text {th }}$ century, Byzantine coins of Justinian, a clay dish with Christian symbols in the form of crosses and images of birds, the stigma of Ephesus ergastiria were found. The city of Tiritaka near Panticapaeum also survived.

The Bosporus did not lose its significance as an outpost of the empire and a transit center in Eastern Crimea in the latter half of the $6^{\text {th }}$ century. Thus, in 569, the Zimarch embassy to the Turks passed through the Bosporus. In 575, the emperor Tiberius published a short story about the liberation of Bosporus and Kherson from naval service.

The Bosporus inscriptions of the Justinian and Mauritius epochs mention exclusively Byzantine emperors, as well as the Byzantine posts of their representatives: tribunes and stratilates, and dating is carried out only in the Byzantine manner, according to indicators. This indicates the strengthening of the empire in the Bosporus.

In 576, the Bosporus and its surroundings were conquered and destroyed by a Turkic force led by Khan Turksanf, who burned the capital. 
All the fortresses and small towns of the Bosporus were destroyed, of which traces of conflagrations witness. The population has declined sharply. Part of the population went west to Chersonesos, homes and necropolises were abandoned and completely occupied by outlanders. It was later that the mass Christianization of the region began, which is marked by the emergence of cemeteries with simple uninventorial soil graves.

The Turkut invasion marked the end of the Late Antique era in the Bosporus and the beginning of a new stage associated with the arrival of the Khazars and subsequently the formation of the Khazar-Byzantine condominium over the Bosporus. Byzantium soon regained power in the Bosporus, but internal changes allow us to talk about the onset of the Middle Ages on this very distant periphery of the late antique world.

Thus, the extreme northeastern periphery of the Late Antique (Early Byzantine) world combined in its history both specific and civilizational aspects, giving a peculiar variant of transitivity.

Translated from Russian by Alexander M. Amatov

Received March 17, 2020

Published December 14, 2020 